\title{
Evidence that high variation in antral follicle count during follicular waves is linked to alterations in ovarian androgen production in cattle
}

\author{
F Mossa, F Jimenez-Krassel ${ }^{1}$, J K Folger ${ }^{1}$, J L H Ireland ${ }^{1}$, G W Smith ${ }^{2}$, P Lonergan, A C O Evans \\ and J J Ireland ${ }^{1,2}$
}

School of Agriculture Food Science and Veterinary Medicine, and Conway Institute of Biomedical and Biomolecular Research, College of Life Sciences, University College Dublin, Belfield, Dublin 4, Ireland, ${ }^{1}$ Molecular Reproductive Endocrinology Laboratory and ${ }^{2}$ Laboratory of Mammalian Reproductive Biology and Genomics, Department of Animal Science, Michigan State University, Room 1230, Anthony Hall, East Lansing, Michigan 48824-1225, USA

Correspondence should be addressed to J J Ireland at Laboratory of Mammalian Reproductive Biology and Genomics, Department Animal Science, Michigan State University; Email: ireland@msu.edu

\begin{abstract}
Androgens have an important role in ovarian follicular growth and function, but circulating androgen concentrations are also associated with ovarian dysfunction, cardiovascular disease, and metabolic disorders in women. The extent and causes of the variation in androgen production in individuals, however, are unknown. Because thecal cells of follicles synthesize androstenedione and testosterone, variation in production of these androgens is hypothesized to be directly related to the inherently high variation in number of healthy growing follicles in ovaries of individuals. To test this hypothesis, we determined whether thecal CYP17A1 mRNA (codes for a cytochrome P450 enzyme involved in androgen synthesis), LH-induced thecal androstenedione production, androstenedione concentrations in follicular fluid, and circulating testosterone concentrations were lower in cattle with relatively low versus high number of follicles growing during follicular waves and whether ovariectomy reduced serum testosterone concentrations. Results demonstrated that cattle with a low follicle number had lower $(P<0.05)$ abundance of $C Y P 17 A 1 \mathrm{mRNA}$ in thecal cells, reduced $(P<0.01)$ capacity of thecal cells to produce androstenedione in response to $\mathrm{LH}$, lower $(\boldsymbol{P}<\mathbf{0 . 0 1})$ androstenedione concentrations in ovulatory follicles, and lower $(P<0.02)$ circulating testosterone concentrations during estrous cycles compared with animals with high follicle number. Also, serum testosterone in cattle with low or high follicle number was reduced by 63 and $70 \%$, respectively, following ovariectomy. In conclusion, circulating androgen concentrations are lower in cattle with low versus high number of follicles growing during follicular waves, possibly because of a reduced responsiveness of thecal cells to $\mathrm{LH}$.

Reproduction (2010) $140713-720$
\end{abstract}

\section{Introduction}

Androgens provide substrate for estradiol $\left(\mathrm{E}_{2}\right)$ production, which is crucial for the development and function of ovulatory follicles and thus reproductive success (King et al. 2007, Walters et al. 2008). In addition, circulating androgen concentrations are associated with ovarian disorders such as polycystic ovarian syndrome (PCOS; Dumesic et al. 2007), cardiovascular health (Wu \& von Eckardstein 2003), and metabolic disease in women (Padmanabhan et al. 2006, Chen et al. 2008). While the primary tissue sources of androgens in healthy non-pregnant females are the ovaries and adrenal glands, the extent and causes of the variation in androgen production among individuals are unknown. Because thecal cells of growing follicles synthesize two potent androgens, androstenedione and testosterone, variation in production of these androgens (by individual follicles), and correspondingly in circulating androgen concentrations (from the total pool of follicles), is hypothesized to be directly related to the inherently high variation in total number of healthy growing follicles in ovaries of individuals.

Previous studies from our laboratories show that serial ovarian ultrasonography can be used to reliably identify cattle that consistently have low or high number of follicles during follicular waves (Burns et al. 2005, Ireland et al. 2007), and that the variation in the peak antral follicle count (AFC) is positively associated with size of the ovarian reserve (total number of morphologically healthy follicles and oocytes in ovaries; Ireland et al. 2008), but inversely associated with 
secretion of gonadotropins during the estrous cycle (Burns et al. 2005, Ireland et al. 2008, 2009, Mossa et al. 2010). Specifically, young adult cattle with low AFC have chronically high circulating $\mathrm{LH}$ concentrations (Jimenez-Krassel et al. 2009), and this could lead to an enhanced production of testosterone by thecal cells. However, the capacity to produce progesterone in response to $\mathrm{LH}$ is lower for luteinized granulosal cells isolated from dominant follicles and for luteal cells of animals with low versus high AFC, despite similar amounts of $\mathrm{LH}$ receptor binding sites, indicating a possible disruption of the LH signaling system in cattle with a relatively low number of follicles growing during follicular waves (Jimenez-Krassel et al. 2009).

Consequently, to test the aforementioned hypothesis, this study used the bovine AFC model to determine whether 1) abundance of thecal CYP17A1 mRNA, which codes for a member of the cytochrome P450 superfamily of enzymes involved in androgen synthesis, 2) androstenedione production by thecal cells in vitro, 3) concentrations of androstenedione in follicular fluid (FF) of ovulatory follicles, 4) circulating testosterone concentrations during estrous cycles were greater in cattle with high versus low AFC, and 5) whether serum testosterone concentrations decreased following ovariectomy and removal of the ovarian reserve in cattle.

\section{Results}

\section{Alterations in CYP17A1 mRNA in thecal cells from cattle with low versus high $A F C$}

As reported previously (Ireland et al. 2009), diameters of the three largest follicles per pair of ovaries combined, collected during the first 2 to 3 days of the follicular wave, were similar $(P>0.05 ; 6.1 \pm 0.3$ vs $5.4 \pm 0.3 \mathrm{~mm})$ for animals in the low versus high AFC groups. However, analysis of mRNA in thecal cells of these follicles showed that the abundance of CYP17A1 mRNA was $60 \%$ lower $(P<0.05)$ in cells isolated from cattle with low versus high AFC $(0.74 \pm 0.22$ vs $1.83 \pm 0.61)$. FF samples were exhausted after completion of other assays, thus androgen concentrations in FF could not be determined in this study.

\section{Alterations in basal and LH-induced androstenedione production by thecal cells of antral follicles of cattle with low versus high follicle number}

Although there was no difference in basal androstenedione production, LH-stimulated androstenedione production was 2.5-fold higher $(P<0.05)$ for thecal cells isolated from cattle in the high versus the low follicle number groups (Fig. 1).

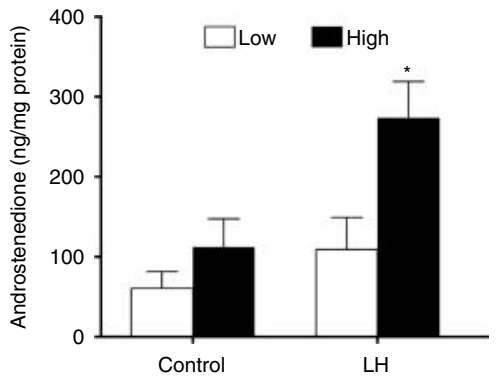

Figure 1 Alterations in basal and $\mathrm{LH}$-induced thecal production of androstenedione in cattle with low versus high AFC. Androstenedione production by theca interna isolated from first-wave dominant follicles of ovaries from animals with low $(n=3)$ or high $(n=3)$ AFC. Theca interna (2 pieces per well) from each follicle were cultured in duplicate for $24 \mathrm{~h}$ with or without $4 \mathrm{ng} / \mathrm{ml} \mathrm{LH}$ as described previously (Lv et al. 2009). Androstenedione production was normalized to total protein contained in thecal tissue after culture. Each bar represents the mean \pm S.E.M. for each follicle number group. Asterisk indicates significant $(P<0.05)$ difference between means.

\section{Alterations in intrafollicular concentrations of androstenedione in ovulatory follicles of cattle with low versus high AFC}

Within $12 \mathrm{~h}$ after the prostaglandin (PG) injection to induce luteolysis and dominant follicle development, diameter $(15.74 \pm 0.36$ vs $14.74 \pm 0.42 \mathrm{~mm})$ and progesterone concentrations in FF $(123 \pm 14$ vs 101 $\pm 7 \mathrm{ng} / \mathrm{ml})$ of ovulatory follicles were similar $(P>0.05)$ for animals in the low versus high AFC groups. In contrast, intrafollicular concentrations of androstenedione were $77 \%(P<0.03, \quad 32.67 \pm 6.45$ vs 109.55 $\pm 25.87 \mathrm{ng} / \mathrm{ml})$ and of $\mathrm{E}_{2}$ were $26 \%(P<0.01 ; 435 \pm 59$ vs $588 \pm 76 \mathrm{ng} / \mathrm{ml}$ ) lower in FF aspirated from ovulatory follicles of animals with low versus high AFC.

\section{Alterations in serum testosterone concentrations during estrous cycles of beef heifers and dairy cows with low versus high AFC}

Serum testosterone concentrations varied $(P<0.01)$ during the days of the estrous cycles of both beef heifers and non-lactating dairy cows. Although testosterone concentrations were lower in dairy cows $(0.04 \pm 0$ vs $0.10 \pm 0.01$ ), patterns of testosterone secretion were similar for animals with low or high AFC (data not shown). Nevertheless, animals with low AFC had an overall lower $(P<0.02)$ serum concentration of testosterone between days 0 and 14 of the estrous cycle for beef heifers and between days 6 and 21 for non-lactating dairy cows compared with animals with high AFC (Fig. 2). In addition, serum testosterone concentrations were lower $(P<0.05)$ on days $2(0.03 \pm 0.01$ vs 0.09 $\pm 0.03 \mathrm{ng} / \mathrm{ml})$ and $3(0.03 \pm 0.01 \mathrm{vs} 0.08 \pm 0.03 \mathrm{ng} / \mathrm{ml})$ of the estrous cycle in beef heifers and on days 8 and $12-16$ of the cycle in non-lactating dairy cows (Fig. 2) for animals in the low versus high AFC groups. 


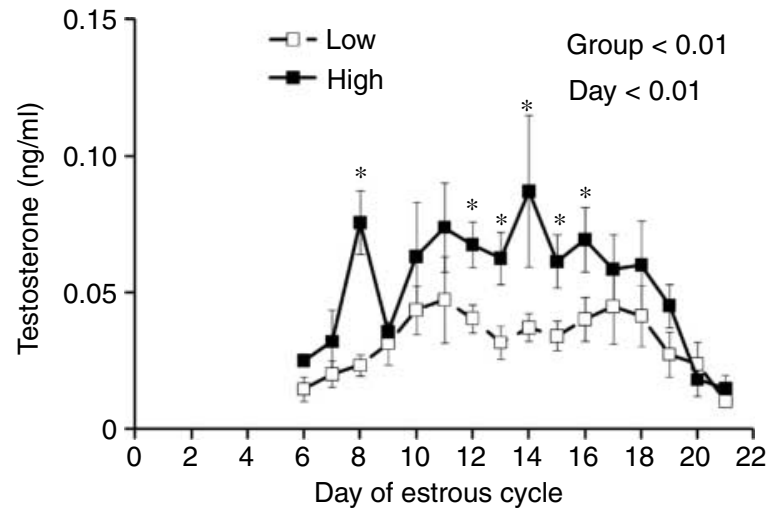

Figure 2 Alterations in serum testosterone concentrations during estrous cycles of dairy cows with low versus high AFC. Concentration of testosterone in serum in Holstein cows with low (open symbols, $n=5$ animals) versus high (solid symbols, $n=4$ ) AFC. Animals were synchronized with two injections of PG administered 11 days apart, and blood samples were collected daily from day 6 to 21 of the estrous cycle. Ovulation occurred on day 1 of the estrous cycle, and ovulation was defined as the day of disappearance of largest dominant follicle as determined by ovarian ultrasonography. ANOVA indicated that there were highly statistically significant $(P<0.02)$ differences in testosterone concentrations during the estrous cycle (day) and between AFC groups (group). Asterisks indicate significant $(P<0.05)$ difference between means. Each symbol represents the daily mean \pm s.E.M. for animals in each AFC group.

\section{Alterations in serum testosterone concentrations after ovariectomy of cattle with low versus high AFC}

The average testosterone concentrations decreased $(P<0.0001)$ by 70 and $63 \%$ by 9 days after ovariectomy in the high and low AFC groups, respectively, compared with overall average testosterone concentrations before ovariectomy collected on day 1,5 , and 10 of the estrous cycle (day 0). Testosterone concentrations were not different before or after surgery between the high and low AFC groups (Fig. 3).

\section{Discussion}

The most significant finding of this study is that ovarian androgen production is positively associated with the number of antral follicles $\geq 3 \mathrm{~mm}$ in diameter. Several diverse lines of evidence strongly support this conclusion. First, in cattle with low AFC, the abundance of thecal CYP17A1 mRNA, which codes for a cytochrome P450 enzyme involved in androgen synthesis, responsiveness of thecal cells to $\mathrm{LH}$ treatment and FF concentrations of androstenedione in ovulatory follicles were diminished compared with that in cattle with a high AFC. Secondly, serum testosterone concentrations were lower overall during estrous cycles of young adult beef cattle and older dairy cows with low versus high AFC. Thirdly, surgical removal of ovaries, and thereby the ovarian reserve, markedly reduced serum testosterone concentrations in cattle. Taken together, these findings imply that follicular androgen production by thecal cells is linked positively to number of follicles growing during follicular waves and correspondingly to the size of the ovarian reserve in cattle, which explains why ovarian androgen production is relatively low during estrous cycles for cattle with low versus high AFC.

Several key questions arise from these novel findings. First, why is androgen production inversely associated with LH secretion? Secondly, what is the impact, if any, of the differences in ovarian androgen production between cattle with low or high AFC on fertility and on other physiological systems?

We previously demonstrated that cattle with low versus high AFC have a twofold greater basal LH concentration (Jimenez-Krassel et al. 2009), whereas the present work shows that both the circulating testosterone concentrations during the estrous cycle and $\mathrm{LH}$-induced androstenedione production by theca cells are lower in cattle with a low versus high AFC. Considering that steroidogenic activity of thecal cells is mainly regulated by $\mathrm{LH}$ ( $\mathrm{Li}$ et al. 2010), and that the inherent capacity of the pituitary gland to produce gonadotropins is not influenced by AFC (Mossa et al. 2010), this discrepancy could be due to a reduced responsiveness of thecal cells to $\mathrm{LH}$ for cattle with a low AFC. This hypothesis is confirmed by the recent finding that the capacity of luteinized granulosal cells isolated from dominant follicles and of luteal cells isolated from CL on day 12 of the estrous cycle to produce progesterone basally and in response to $\mathrm{LH}$ are lower for cattle with low versus high AFC (Jimenez-Krassel et al. 2009). Moreover, two recent studies showed that LH significantly increased androstenedione production in bovine thecal cells (in accordance with our results), and that addition of two inhibitors of the phosphatidylinositol-3-kinase/Akt signaling pathway significantly decreased $\mathrm{LH}$-induced androstenedione production (Fukuda et al. 2009), inhibition of the Akt and Erk pathway inhibited both basal and LH-induced androstenedione secretion by

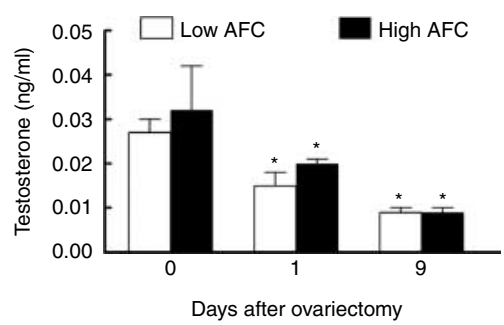

Figure 3 Alterations in serum testosterone concentrations after ovariectomy of cattle with low versus high AFC. Circulating concentrations of testosterone were measured in Holstein cows with low (open symbols, $n=5$ animals) versus high (solid symbols, $n=4$ ) AFC. Animals were synchronized with PG and blood samples collected at various times before (day 5 and 10 of estrous cycle and $1 \mathrm{~h}$ before ovariectomy) and 1 and 9 days after ovariectomy as explained in Materials and Methods. The zero time point represents the pooled mean \pm S.E.M. for day 5 and 10 of the estrous cycle and $1 \mathrm{~h}$ before ovariectomy for cows in the low or high AFC groups. Asterisks indicate significant $(P<0.01)$ difference from day 0 values. 
bovine theca cells in vitro (Ryan et al. 2008). Recent evidence shows that LH significantly increases CYP17A1 mRNA expression in thecal cells (Fukuda et al. 2009), and in this study, it was shown that CYP17A1 mRNA expression was higher in thecal cells from cattle with a high AFC, despite lower basal and episodic LH secretion (Jimenez-Krassel et al. 2009). Therefore, the reduced androgen production in animals with a low AFC could be due to an alteration in $\mathrm{LH}$ signaling which, in turn, may alter CYP17A1 mRNA expression.

We have recently shown that intrafollicular $E_{2}$ concentration in the three largest follicles $(5-7 \mathrm{~mm})$ at emergence of the follicular wave is greater in cattle with low versus high AFC (Ireland et al. 2009). In contrast, it was found that intrafollicular $E_{2}$ concentrations were lower in ovulatory follicles $(14-15 \mathrm{~mm}$ ) in cattle with low versus high AFC in this study. While several explanations are possible, this difference in $\mathrm{E}_{2}$ production by the two different follicle types could be due to the reduced responsiveness of dominant compared with smaller antral follicles to LH in cattle with low AFC. In support of this possibility, it is well established that granulosal and thecal cells of dominant follicles develop LH receptors in sheep and cattle (Webb \& Campbell 2007). Therefore, the lower sensitivity of granulosal and thecal cells to $\mathrm{LH}$ in cattle with low versus high AFC could also explain the lower intrafollicular $E_{2}$ and androstenedione concentrations at the ovulatory, LH-dependent stage of follicular development, as observed in this study.

Ovarian AFC is inversely associated with circulating FSH concentrations during the estrous cycle (Burns et al. 2005, Ireland et al. 2008, 2009, Mossa et al. 2010), and there is evidence suggesting a reciprocal control between androgens and ovarian sensitivity to FSH. For example, in vivo treatment with testosterone increases androgen receptor mRNA in granulosal and thecal cells in small antral follicles of primates, and the expression of androgen receptor mRNA is positively correlated with FSH receptor $(F S H R)$ mRNA expression (Weil et al. 1999). In addition, dihydrotestosterone (DHT) increases FSHR expression in preovulatory follicles in gilts (Cardenas et al. 2002), and administration of testosterone or DHT to female rhesus monkeys and pregnant ewes (prenatally treated fetuses) stimulates primordial follicle initiation and increases growing follicle numbers and overall follicle survival (Vendola et al. 1999, Steckler et al. 2005, Forsdike et al. 2007). During oocyte maturation and ovulation, androgens increase abundance of FSHR mRNA and number of preovulatory follicles and corpora lutea (Walters et al. 2008). Testosterone increases murine follicle responsiveness to FSH (Wang et al. 2001), and androstenedione stimulates FSH-mediated differentiation of bovine granulosal cells, as indicated by an increase in aromatase activity and $E_{2}$ production (Hamel et al. 2005). In women, serum androgen levels are correlated with the ovarian response to $\mathrm{FSH}$, as assessed by the peak $\mathrm{E}_{2}$ levels and the number of follicles and number of oocytes and embryos retrieved (Barbieri et al. 2005), and significant positive correlations exist between the AFC and both baseline and stimulated steroid serum concentrations (Hugues et al. 2010). Therefore, cattle with a high AFC and higher serum androgen concentrations could have an enhanced ovarian sensitivity to $\mathrm{FSH}$, and this could in turn explain why a greater number of follicles are recruited per wave, despite the lower serum concentrations of FSH compared with cattle with a lower AFC. Moreover, we have recently demonstrated that the inherent capacity of the pituitary gland to produce gonadotropins is not different between cattle with high versus low number of follicles during follicular waves (Mossa et al. 2010), implicating ovarian factors as the more plausible causes of FSH variation.

The possible effects of elevated gonadotropins and relatively low androgen concentrations on fertility are unknown. In women, ovarian aging is characterized by a reduced ovarian sensitivity to $\mathrm{FSH}$, which is accompanied by a progressive decline in serum androgen levels (Davison et al. 2005, Sowers et al. 2009). Several studies show that women with an elevated FSH concentration, independent of age, have a poor response to ovarian stimulation, leading to a lower pregnancy rate using assisted reproduction techniques (Scott et al. 1989, Martin et al. 1996, Sharif et al. 1998, El-Toukhy et al. 2002). However, Abdalla \& Thum (2004) report that elevated basal FSH concentrations are not indicative of deterioration of oocyte and embryo quality and explained the reduction in pregnancy rate as a result of a reduced number of oocytes collected and the subsequently limited choice of embryos available for transfer in women undergoing IVF treatment. Cattle with a low AFC show similarities with aging women, such as increased secretion of FSH (Burns et al. 2005, Ireland et al. 2008), reduced serum progesterone (Jimenez-Krassel et al. 2009) and anti-Mullerian hormone during the estrous cycle (Ireland et al. 2008), reduced ovarian reserve (Ireland et al. 2008), poor response to superovulation (Ireland et al. 2007), and, as our present results show, reduced androgen concentrations during estrous cycles. These findings may suggest an impaired fertility in cattle with low AFC. However, to date, no studies have investigated the association between AFC and reproductive success in cattle. Specifically, the possible effects of the variation in androgen concentrations on reproduction are unknown. For example, the addition of exogenous testosterone $(100 \mathrm{nM})$ to oocyte maturation medium, selected on the basis of physiological concentrations reported in preovulatory bovine follicles ( $165 \mathrm{nM}$; Dieleman et al. 1983), improved the developmental competence of bovine oocytes after IVF (Younis et al. 1989, Silva \& Knight 2000). On the other hand, hyperandrogenism is among the main features of PCOS, one of the most common causes of ovulatory infertility in women (Pasquali \& Gambineri 2006). 
The present results also indicate ovaries as the primary source of androgens in female cattle, regardless of number of follicles. Serum testosterone concentrations did not differ significantly between the two groups of cattle with low or high follicle number before the removal of the ovaries probably because blood was sampled on day 1,5 , and 9 of the estrous cycle when the differences in testosterone concentrations are not statistically significant, as shown in this study. Nevertheless, results of ovariectomy and removal of the ovarian reserve confirm that the ovary is the main source of androgens in cattle.

In conclusion, this study has demonstrated for the first time that responsiveness of thecal cells to $\mathrm{LH}$ is lower in cattle with low versus high number of antral follicles growing during follicular waves as assessed by the reduced capacity of thecal cells to produce androstenedione in response to $\mathrm{LH}$, lower abundance of CYP17A1 mRNA in thecal cells, lower androstenedione concentrations in ovulatory follicles, and diminished circulating testosterone concentrations during estrous cycles. Further studies will be necessary to investigate the possible effects of the variation in the ovarian reserve, and associated androgen production, on fertility as well as the causes of the high variation in numbers of follicles and oocytes in ovaries of mammals.

\section{Materials and Methods}

\section{Animals}

Cattle used in experiments were located at the Michigan State University Beef or Dairy Cattle Teaching and Research Centers or Lyons Research Farm, University College Dublin, Ireland. All experiments were performed in compliance with protocols approved by the All University Committee on Animal Use and Care at Michigan State University or the Animal Research Ethics Subcommittee, University College Dublin, the Cruelty to Animal Act (Ireland, 1876), and the European Union Directive 86/609/EC.

\section{Identification of cattle with consistently low versus high AFC during follicular waves}

Ovaries of each animal were monitored with an Aloka SSD900 ultrasound machine using a linear array trans-rectal probe (7.5 MHz transducer), and follicles were counted as described previously (Burns et al. 2005, Ireland et al. 2007, 2008, 2009). Each antral follicle $\geq 3 \mathrm{~mm}$ in diameter was drawn on an ovarian map, and diameter and total number of follicles $\geq 3 \mathrm{~mm}$ in diameter per pair of ovaries, hereafter referred to as AFC, were recorded for each animal. Cattle that consistently had a relatively low versus high peak AFC during follicular waves were identified as explained previously (Burns et al. 2005). Briefly, a group of adult animals of similar ages and weights were injected two or three times with $\mathrm{PGF}_{2 \alpha}$ spaced 11 days apart to initiate luteolysis and to synchronize occurrence of ovulation. Ovaries were then subjected to once or twice daily ovarian ultrasonography to determine AFC beginning on days 1 to 2 after the last PG injection and continuing until completion of the study. Ovulation day was defined as the first day that the preovulatory follicle was not observed by ultrasonography. Peak AFC was determined for three to five follicular waves per animal, and the average peak value for AFC per wave was used to classify cattle into the low ( $\leq 15$ follicles) or high ( $\geq 25$ follicles) AFC groups (Burns et al. 2005, Ireland et al. 2007, 2008, 2009, Mossa et al. 2010). Animals in the intermediate category (16-24 follicles) were not studied further and were returned to the herd.

In previously published studies (Ireland et al. 2007, 2009, Mossa et al. 2010), 177 cross-bred beef heifers and 116 dairy cows were examined, and $13 \%(n=39)$ were ranked in the low, $76 \%(n=223)$ in the intermediate, and $11 \%(n=31)$ in high AFC groups. The number of animals used in each experiment is specified below.

\section{Alterations in CYP17A1 mRNA in thecal cells from cattle with low versus high AFC}

Thirty-two cross-bred beef heifers (Hereford $\times$ Angus $\times$ Charolais, 11-13 months of age) were initially used for this experiment, and heifers were assigned to one of two groups as described above: low ( $\leq 15$ follicles, $n=5$ animals) or high ( $\geq 25$ follicles, $n=5$ animals). Remaining animals in the intermediate category $(n=22)$ were excluded. Thecal cells were obtained from each of the three largest growing follicles per pair of ovaries during the early stages of the first follicular wave on days 2-3 of the estrous cycle for adult beef heifers $(n=3$ largest follicles per pair of ovaries for five animals per group) with low versus high AFC as explained previously (Ireland et al. 2009). Abundance of CYP17A1 mRNA was measured in thecal cells as explained below.

\section{Alterations in basal and $\mathrm{LH}$-induced androstenedione production by thecal cells of dominant follicles from cattle with low versus high number of follicles}

Thecal cells were obtained from first-wave dominant follicles (Ireland et al. 1980) isolated from ovaries obtained at an abattoir from cattle with high $(\geq 25$ follicles $\geq 3 \mathrm{~mm}$ in diameter, $n=3$ animals) or low ( $\leq 15$ follicles $\geq 3 \mathrm{~mm}$ in diameter, $n=3$ animals) follicle number. The theca interna was dissected from the follicle, scraped clean of granulosal cells, and cut into eight pieces. Pieces of theca (two per well) from each animal were then separately cultured for $24 \mathrm{~h}$ with 0 or $4 \mathrm{ng} / \mathrm{ml}$ of bLH (NIH AFP-11743B), as described previously (Lv et al. 2009). After culture, the media were aspirated and stored at $-20{ }^{\circ} \mathrm{C}$ until determination of androstenedione concentration, and the theca pieces were snap frozen in liquid nitrogen and stored at $-80^{\circ} \mathrm{C}$. The theca pieces were then lysed by homogenization and sonication in ice-cold RIPA buffer (Sigma) plus Complete Protease Inhibitor Cocktail Tablet (Roche). Lysates were centrifuged (10 $000 \mathrm{~g}$ for $10 \mathrm{~min}$ at $4{ }^{\circ} \mathrm{C}$ ), and protein in the supernatant was determined with the use of the DC Protein Assay (Bio-Rad). Data were expressed as nanogram androstenedione per mg protein. 


\section{Alterations in intrafollicular concentrations of androstenedione in ovulatory follicles of cattle with low versus high AFC}

Fifty-five cross-bred beef heifers (12-14 months of age) were examined, and animals with low $(n=7)$, intermediate $(n=38)$, and high $(n=10)$ AFC were identified as described previously; heifers in the intermediate group were excluded from the experiment and returned to the herd. On day 7 of the estrous cycle during the first follicular wave, PG was injected, and $12 \mathrm{~h}$ later, the diameter of the ovulatory follicle was measured using ultrasonography, and FF was collected from the dominant ovulatory follicle (largest) via ultrasound-guided follicular aspiration (Jimenez-Krassel et al. 2003). Granulosal cells were separated by centrifugation, and FF was frozen within 15 min of collection. After thawing, concentration of androstenedione, progesterone, and $E_{2}$ were determined for each aspirated FF supernatant.

\section{Alterations in serum testosterone concentrations during estrous cycles of beef heifers and dairy cows with low versus high AFC}

As reported previously (Ireland et al. 2007), 90 cross-bred beef heifers (11-12 months of age) were segregated into the low $(n=14)$, intermediate $(n=65)$, and high $(n=11)$ AFC groups. A subset of heifers with low ( $n=7$ animals) versus high $(n=7)$ AFC were synchronized with two injections of PG administered 11 days apart. Daily blood samples were collected from the day of injecting second PG to day 14 of the estrous cycle. In a second previously published study (Mossa et al. 2010), 116 non-lactating Holstein cows (4-8 years of age) were examined, and cattle with low ( $n=5$ animals) versus high $(n=4)$ AFC were selected and synchronized with two injections of PG administered 11 days apart. After the second PG injection, daily blood samples were collected from day 6 to 21 of the estrous cycle. Blood samples from cows of the two previously published studies (Ireland et al. 2009, Mossa et al. 2010) were used as the source of serum samples for testosterone analysis in this study.

\section{Alterations in serum testosterone concentrations after ovariectomy of cattle with low versus high AFC}

To investigate the contribution of the ovaries in animals with high or low AFC to circulating androgen concentrations, this study determined whether ovariectomy altered serum testosterone concentrations in cattle with low or high AFC. The same non-lactating Holstein cows (4-8 years of age) with low ( $n=5$ animals) or high $(n=4)$ AFC used in a previous study (Mossa et al. 2010) and for serum testosterone determinations as explained above were also used in this study. Testosterone concentrations were determined in blood samples collected on days 5 and 10 of the estrous cycle. In addition, estrous cycles were synchronized with two injections of PG spaced 11 days apart. Ten days later, cows received two additional injections of PG $16 \mathrm{~h}$ apart to ensure rapid luteolysis; and 22-28 h after the fourth PG injection, cows were bilaterally ovariectomized via colpotomy
(Drost et al. 1992). Blood samples were collected $1 \mathrm{~h}$ before and 1 and 9 days after ovariectomy to monitor alterations in serum testosterone concentrations.

\section{Hormone analyses}

Total testosterone in serum was measured following ether extraction of serum samples $(0.5 \mathrm{ml})$ using commercially available RIA kits (Siemens Medical Solutions Diagnostics, Los Angeles, CA, USA; Cruinn Diagnostics Ltd, Dublin, Ireland). Inter- and intra-assay coefficients of variation (CV) were $<13 \%$, and limit of detection was $0.03 \mathrm{ng} / \mathrm{ml}$.

Concentrations of androstenedione, progesterone, and $E_{2}$ in FF or media were analyzed using commercially available kits from Siemens Medical Solutions Diagnostics. Intra-assay CV were $<10 \%$ for each assay.

\section{mRNA analysis}

Total RNA was extracted from thecal cells of each follicle and processed for analysis by real-time PCR as explained previously (Ireland et al. 2009). Primers for bovine CYP17A1 were forward 5'-CAAGGATGGCAACCTGAAGT-3' and reverse 5'-GAGAGAGAGGCTCGGACAGA-3'. Abundance of CYP17A1 mRNA was normalized against levels of the constitutively expressed housekeeping gene $A C T B$, and relative amounts of gene expression were calculated using the formula $2^{-\left(\Delta \Delta C_{\mathrm{t}}\right)}$ (Livak \& Schmittgen 2001).

\section{Statistical analyses}

Testosterone concentrations in serum of intact animals before and after ovariectomies were analyzed using Proc Mixed procedure of SAS (1995). Data were examined for normality of distribution with the Shapiro-Wilk test, and when heterogeneity of variance was detected, data were natural logtransformed before analyses, but actual values are reported. The model included the effects of group (low versus high), day of estrous cycle, and their interaction. Day of blood sampling was treated as a repeated measure across individual animals. When main effects were significant, a Bonferroni's $t$-test was used to determine if statistically significant $(P \leq 0.05)$ differences existed among individual means.

Concentrations of steroids in FF or media and abundance of thecal mRNA for CYP17A1 were statistically analyzed using the Proc Mixed model of SAS (1995). Data were examined for normality of distribution as described above. Main effects included animal groups (low versus high). When main effects were significant $(P<0.05)$, a Bonferroni's $t$-test was used to determine if statistically significant $(P<0.05)$ differences existed among individual means.

\section{Declaration of interest}

The authors declare that there is no conflict of interest that could be perceived as prejudicing the impartiality of the research reported. 


\section{Funding}

The work was supported by National Research Initiative Competitive Grants 2001-002255, 2004-01697, and 200701289 from the USDA Cooperative State Research, Education and Extension Service and by the Irish Department of Agriculture, Fisheries and Food Research Stimulus Fund programme 2006 (RSF 06-328).

\section{Acknowledgements}

The authors thank A Crudgington, P Furney, E Gallagher, and $P$ Duffy for their technical support.

\section{References}

Abdalla H \& Thum MY 2004 An elevated basal FSH reflects a quantitative rather than qualitative decline of the ovarian reserve. Human Reproduction 19 893-898. (doi:10.1093/humrep/deh141)

Barbieri RL, Sluss PM, Powers RD, McShane PM, Vitonis A, Ginsburg E \& Cramer DC 2005 Association of body mass index, age, and cigarette smoking with serum testosterone levels in cycling women undergoing in vitro fertilization. Fertility and Sterility 83 302-308. (doi:10.1016/ j.fertnstert.2004.07.956)

Burns DS, Jimenez-Krassel FJ, Ireland JLH, Knight PG \& Ireland JJ 2005 Numbers of antral follicles during follicular waves in cattle: evidence for high variation among animals, very high repeatability in individuals, and an inverse association with serum follicle-stimulating hormone concentrations. Biology of Reproduction 73 54-62. (doi:10.1095/biolreprod. 104.036277)

Cardenas H, Herrick JR \& Pope WF 2002 Increased ovulation rate in gilts treated with dihydrotestosterone. Reproduction 123 527-533. (doi:10. 1530/rep.0.1230527)

Chen M-J, Yang W-S, Chen C-L, Wu M-Y, Yang Y-S \& Ho H-N 2008 The relationship between anti-Mullerian hormone, androgen and insulin resistance on the number of antral follicles in women with polycystic ovary syndrome. Human Reproduction 23 952-957. (doi:10.1093/ humrep/den015)

Davison SL, Bell R, Montalto JG, Sikaris K, Donath S, Stanczyk FZ \& Davis SR 2005 Measurement of total testosterone in women: comparison of a direct radioimmunoassay versus radioimmunoassay after organic solvent extraction and celite column partition chromatography. Fertility and Sterility 84 1698-1704. (doi:10.1016/j.fertnstert. 2005.05.058)

Dieleman SJ, Kruip TA, Fontijne P, de Jong WH \& van der Weyden GC 1983 Changes in oestradiol, progesterone and testosterone concentrations in follicular fluid and in the micromorphology of preovulatory bovine follicles relative to the peak of luteinizing hormone. Journal of Endocrinology 97 31-42. (doi:10.1677/joe.0.0970031)

Drost M, Savio JD, Barros CM, Badinga L \& Thatcher WW 1992 Ovariectomy by colpotomy in cows. Journal of the American Veterinary Medical Association 200 337-339.

Dumesic D, Abbott D \& Padmanabhan V 2007 Polycystic ovary syndrome and its developmental origins. Reviews in Endocrine and Metabolic Disorders 8 127-141. (doi:10.1007/s11154-007-9046-0)

El-Toukhy T, Khalaf Y, Hart R, Taylor A \& Braude P 2002 Young age does not protect against the adverse effects of reduced ovarian reserve - an eight year study. Human Reproduction 17 1519-1524. (doi:10.1093/humrep/ 17.6.1519)

Forsdike RA, Hardy K, Bull L, Stark J, Webber LJ, Stubbs S, Robinson JE \& Franks S 2007 Disordered follicle development in ovaries of prenatally androgenized ewes. Journal of Endocrinology 192 421-428. (doi:10. 1677/joe.1.07097)

Fukuda S, Orisaka M, Tajima K, Hattori K \& Kotsuji F 2009 Luteinizing hormone-induced Akt phosphorylation and androgen production are modulated by MAP kinase in bovine theca cells. Journal of Ovarian Research 2 17. (doi:10.1186/1757-2215-2-17)
Hamel M, Vanselow J, Nicola ES \& Price CA 2005 Androstenedione increases cytochrome P450 aromatase messenger ribonucleic acid transcripts in nonluteinizing bovine granulosa cells. Molecular Reproduction and Development 70 175-183. (doi:10.1002/mrd.20194)

Hugues JN, Theron-Gerard L, Coussieu C, Pasquier M, Dewailly D \& Cedrin-Durnerin I 2010 Assessment of theca cell function prior to controlled ovarian stimulation: the predictive value of serum basal/ stimulated steroid levels. Human Reproduction 25 228-234. (doi:10. 1093/humrep/dep378)

Ireland JJ, Murphree RL \& Coulson PB 1980 Accuracy of predicting stages of bovine estrous cycle by gross appearance of the corpus luteum. Journal of Dairy Science 63 155-160. (doi:10.3168/jds.S00220302(80)82901-8)

Ireland JJ, Ward F, Jimenez-Krassel F, Ireland JLH, Smith GW, Lonergan P \& Evans ACO 2007 Follicle numbers are highly repeatable within individual animals but are inversely correlated with FSH concentrations and the proportion of good-quality embryos after ovarian stimulation in cattle. Human Reproduction 22 1687-1695. (doi:10.1093/humrep/ dem071)

Ireland JLH, Scheetz D, Jimenez-Krassel F, Themmen APN, Ward F, Lonergan P, Smith GW, Perez GI, Evans ACO \& Ireland JJ 2008 Antral follicle count reliably predicts number of morphologically healthy oocytes and follicles in ovaries of young adult cattle. Biology of Reproduction 79 1219-1225. (doi:10.1095/biolreprod.108.071670)

Ireland J, Zielak AE, Jimenez-Krassel F, Folger J, Bettegowda A, Scheetz D, Walsh S, Mossa F, Knight PG, Smith GW et al. 2009 Variation in the ovarian reserve is linked to alterations in intrafollicular estradiol production and ovarian biomarkers of follicular differentiation and oocyte quality in cattle. Biology of Reproduction 80 954-964. (doi:10. 1095/biolreprod.108.073791)

Jimenez-Krassel F, Winn ME, Burns D, Ireland JLH \& Ireland JJ 2003 Evidence for a negative intrafollicular role for inhibin in regulation of estradiol production by granulosa cells. Endocrinology 144 1876-1886. (doi:10.1210/en.2002-221077)

Jimenez-Krassel F, Folger J, Ireland JLH, Smith GW, Hou X, Davis JS, Lonergan P, Evans ACO \& Ireland JJ 2009 Evidence that high variation in ovarian reserves of healthy young adults has a negative impact on the corpus luteum and endometrium during reproductive cycles of singleovulating species. Biology of Reproduction 80 1272-1281. (doi:10. 1095/biolreprod.108.075093)

King AJ, Bari Olivier N, Mohankumar PS, Lee JS, Padmanabhan V \& Fink GD 2007 Hypertension caused by prenatal testosterone excess in female sheep. American Journal of Physiology. Endocrinology and Metabolism 292 E1837-E1841. (doi:10.1152/ajpendo.00668.2006)

Li M, Xue K, Ling J, Diao FY, Cui YG \& Liu JY 2010 The orphan nuclear receptor NR4A1 regulates transcription of key steroidogenic enzymes in ovarian theca cells. Molecular and Cellular Endocrinology 319 39-46. (doi:10.1016/j.mce.2010.01.014)

Livak KJ \& Schmittgen TD 2001 Analysis of relative gene expression data using real-time quantitative PCR and the $2^{-\Delta \Delta C_{\mathrm{t}}}$ method. Methods 25 402-408. (doi:10.1006/meth.2001.1262)

Lv L, Jimenez-Krassel F, Sen A, Bettegowda A, Mondal M, Folger JK, Lee K-B, Ireland JJ \& Smith GW 2009 Evidence supporting a role for cocaine- and amphetamine-regulated transcript (CARTPT) in control of granulosa cell estradiol production associated with dominant follicle selection in cattle. Biology of Reproduction 81 580-586. (doi:10.1095/ biolreprod.109.077586)

Martin JS, Nisker JA, Tummon IS, Daniel SA, Auckland JL \& Feyles V 1996 Future in vitro fertilization pregnancy potential of women with variably elevated day 3 follicle-stimulating hormone levels. Fertility and Sterility $651238-1240$.

Mossa F, Jimenez-Krassel F, Walsh S, Berry DP, Butler S, Folger J, Smith GW, Ireland JLH, Lonergan P, Ireland JJ et al. 2010 The inherent capacity of the pituitary gland to produce gonadotropins is not influenced by the number of ovarian follicles $\geq 3 \mathrm{~mm}$ in diameter in cattle. Reproduction, Fertility, and Development 22 550-557. (doi:10. 1071/RD09100)

Padmanabhan V, Manikkam M, Recabarren S \& Foster D 2006 Prenatal testosterone excess programs reproductive and metabolic dysfunction in the female. Molecular and Cellular Endocrinology 246 165-174. (doi:10.1016/j.mce.2005.11.016) 
Pasquali R \& Gambineri A 2006 Polycystic ovary syndrome: a multifaceted disease from adolescence to adult age. Annals of the New York Academy of Sciences 1092 158-174. (doi:10.1196/annals.1365.014)

Ryan KE, Glister C, Lonergan P, Martin F, Knight PG \& Evans AC 2008 Functional significance of the signal transduction pathways Akt and Erk in ovarian follicles: in vitro and in vivo studies in cattle and sheep. Journal of Ovarian Research 1 2. (doi:10.1186/1757-2215-1-2)

SAS Institute Inc. 1995 SAS User's Guide: Statistics. Cary, NC: SAS Institute Inc.

Scott RT, Toner JP, Muasher SJ, Oehninger S, Robinson S \& Rosenwaks Z 1989 Follicle-stimulating hormone levels on cycle day 3 are predictive of in vitro fertilization outcome. Fertility and Sterility 51 651-654.

Sharif K, Elgendy M, Lashen H \& Afnan M 1998 Age and basal follicle stimulating hormone as predictors of in vitro fertilisation outcome. British Journal of Obstetrics and Gynaecology 105 107-112. (doi:10.1111/ j.1471-0528.1998.tb09360.x)

Silva CC \& Knight PG 2000 Effects of androgens, progesterone and their antagonists on the developmental competence of in vitro matured bovine oocytes. Journal of Reproduction and Fertility 119 261-269. (doi:10. 1530/reprod/119.2.261)

Sowers MF, Zheng H, McConnell D, Nan B, Karvonen-Gutierrez CA \& Randolph JF Jr 2009 Testosterone, sex hormone-binding globulin and free androgen index among adult women: chronological and ovarian aging. Human Reproduction 24 2276-2285. (doi:10.1093/humrep/ dep209)

Steckler T, Wang J, Bartol FF, Roy SK \& Padmanabhan V 2005 Fetal programming: prenatal testosterone treatment causes intrauterine growth retardation, reduces ovarian reserve and increases ovarian follicular recruitment. Endocrinology 146 3185-3193. (doi:10.1210/ en.2004-1444)
Vendola K, Zhou J, Wang J, Famuyiwa OA, Bievre M \& Bondy CA 1999 Androgens promote oocyte insulin-like growth factor I expression and initiation of follicle development in the primate ovary. Biology of Reproduction 61 353-357. (doi:10.1095/biolreprod61.2.353)

Walters KA, Allan CM \& Handelsman DJ 2008 Androgen actions and the ovary. Biology of Reproduction 78 380-389. (doi:10.1095/biolreprod. 107.064089)

Wang H, Andoh K, Hagiwara H, Xiaowei L, Kikuchi N, Abe Y, Yamada K, Fatima R \& Mizunuma H 2001 Effect of adrenal and ovarian androgens on type 4 follicles unresponsive to FSH in immature mice. Endocrinology 142 4930-4936. (doi:10.1210/en.142.11.4930)

Webb R \& Campbell BK 2007 Development of the dominant follicle: mechanisms of selection and maintenance of oocyte quality. Society of Reproduction and Fertility Supplement 64 141-163.

Weil S, Vendola K, Zhou J \& Bondy CA 1999 Androgen and folliclestimulating hormone interactions in primate ovarian follicle development. Journal of Clinical Endocrinology and Metabolism 84 2951-2956. (doi:10.1210/jc.84.8.2951)

Wu FCW \& von Eckardstein A 2003 Androgens and coronary artery disease. Endocrine Reviews 24 183-217. (doi:10.1210/er.2001-0025)

Younis AI, Brackett BG \& Fayrer-Hosken RA 1989 Influence of serum and hormones on bovine oocyte maturation and fertilization in vitro. Gamete Research 23 189-201. (doi:10.1002/mrd.1120230206)

Received 7 May 2010

First decision 1 June 2010

Revised manuscript received 6 July 2010

Accepted 10 August 2010 